\title{
Assessment of the Impact of Pro-Poor Growth on Poverty in Developing Countries
}

\author{
Ilhem Zorgui \\ Community College of Jazan University \\ Saudi Arabia and Assistant in FSEG Jendouba, Tunisia. \\ Houda Ayed \\ Economics in FSEG Tunis, Elmanar University and Independent Researcher \\ Said Jaouadi \\ College of Business Administraiton of Jazan University \\ Saudi Arabia and Assistant at the Elmanar University
}

Received: May 20, 2016 Accepted: June 7, 2016

doi:10.5296/ber.v6i2.9484

URL: http://dx.doi.org/10.5296/ber.v6i2.9484

\begin{abstract}
The paper aims at determining the impact of pro-poor growth on poverty in developing countries. The abundant literature regarding the issue of beneficial effects of the raise of national wealth on poor classes provided conflicted findings. In the addition of the theoretical review regarding the surveys attempting to find out the role of growth on poverty, the present paper relies on providing a new framework of analysis to find out the real impact of economic growth on the living conditions of the poor. The empirical analysis stands for the conduct of an empirical research made up of an econometric model applied on a panel of some developing countries.

The empirical research revealed that growth could have a harmful impact on poverty in developing countries. The last finding remains limited because the coefficient is not statistically significant. The illustration of the outcome focuses on the lack of data about ineffective income redistribution, or regarding the contribution of some specific economic field as agriculture.
\end{abstract}

Keywords: Pro-poor growth, Multidimensionality of poverty, Growth. 


\section{Introduction}

From the review of the history of economics, it stems that the combat of humanity against poverty has endured several centuries without a real success to reduce the share of population living in deplorable conditions. Historians considered poverty as a phenomenon that appeared since the advent of the first human civilizations. It took different forms and was more intensive than conditions nowadays. In economics, poverty is assumed as an omnipresent phenomenon in all economies and recorded a rapid increase even in developing countries.

Several studies provide a prime attention for pro-poor growth as new catalyst to eradicate poverty in the world, the new concept is relying on specific type of growth recorded by the country and assumed to increase the resources of poor classes. The bulk of the theoretical approaches relying on fighting poverty in the world, depend on the neo-liberal perspective, they consider the existence of poverty in the economy as ineluctable, due to the institutions weakness. The neo-liberal doctrine continued to play a pivotal role in influencing the formulation of appropriate policies for international organizations to eradicate poverty in developing countries.

The neo-liberal perspective to combat poverty awarded to growth a pivotal role as highway to reduce poverty, under the hypothesis of equitable redistribution of income among the several social classes. The last makes up the topic of several surveys and recent papers because of the prime importance of the issue, and the significance of its introduction in economic policies of developing countries attempting to fight poverty in their territories.

\section{Literature Review}

According to the analysis of several aggregates related to poverty, it seems obvious to denote the widespread of poorness in the world, giving a prime attention for the issue of poverty fight in recent papers. The review of economic theory about identifying the causes of rise of poverty and assessing the different initiatives formulated by international institutions, authorized us to denote that since 1980, the major interventions and policies implemented by international institutions to combat poverty were in accordance with the neo-liberal perspective.

\subsection{Poverty Concept}

The economic definition of the word "poverty" is in accordance with the multiple meaning of the word. In fact, there is diverse methodologies define the poverty notion. For some methodologies, it is more significant to put emphasis on the social dimension of poverty, others assumed that poverty is purely monetary and for another panel of authors, poverty is necessarily institutional.

For UNDP, a person is considered as extremely poor if he has not sufficient income to satisfy his essential needs. For the needs, the international institution defines them through estimating their biological needs in calories.

For World Bank, the institution assumed the headcount ratio of one US dollar per day as threshold for purchasing power to satisfy extreme essential needs. The institution of Bretton 
Woods considered another level of two US dollars per day as indicator of purchasing power to satisfy essential needs.

\subsection{The measure of Poverty}

The above statement underlines the multiplicity of poverty definition due to the diversity of dimensions touched by misery. The various perspectives to provide a new framework of analysis to define poverty made up the major motivation to discuss in depth the concept and the available methods to measure it.

\subsubsection{Absolute Poverty}

Fixing the absolute poverty relies on determining the purchasing power, the line is identified through considering the necessary requirements of people in nutrition. Absolute poverty method seems useful in carrying out comparative surveys among countries or regions.

\subsubsection{Relative Poverty}

The concept of relative poverty focuses on determining the line of poverty using the distribution of revenues or consumption for a specific group. According to the relative poverty notion, someone is poor because he receives less income than others even if he is able to finance his necessary requirements of nutrition.

\subsection{The Theoretical Foundations of Pro-Poor Growth}

During more than two decades, IMF and World Bank encouraged the developing countries to adopt the structural adjustment program, considered by the international institution as a good tool to eradicate poverty. After implementing the program for several years, it finished by recording a fail to improve the social and economic conditions of living of population of developing countries.

After the application of these programs, developing countries recorded negative outcome, many researchers considered that poverty increased in countries after applying the structural adjustment programs. According to Easterly $(2001)^{1}$, the programs consolidated by World Bank and IMF under the implementation of the structural adjustment programs led to an increase of poverty in the developing countries. The obtained findings denied the firm association between growth and poverty highly argued in economic theory. In fact, it allowed international institutions to introduce other dimensions of poverty and to attempt to illustrate the complex relationship between the two concepts.

Since 1990, the new approach attributed a prime attention to the significance of some indicators, such as: GDP per capita, Human poverty index explained by Fukua-Parr $(2006)^{2}$ and the Human development index illustrated by Anand $(1994)^{3}$, considered as better indicating the poverty state of countries, because of the ability of these indicators to sum up

\footnotetext{
${ }^{1}$ Easterly, W. (2003). IMF and World Bank structural adjustment programs and poverty. In Managing currency crises in emerging markets (pp. 361-392). University of Chicago Press.

${ }_{2}^{2}$ Fukuda-Parr, S. (2006). The human poverty index: A multidimensional measure. Poverty in focus: What is poverty? Concepts and measures.

3 Anand, S. (1994). Human Development Index: methodology and measurement (No. HDOCPA-1994-02). Human Development Report Office (HDRO), United Nations Development Programme (UNDP).
} 
several fields of poverty (mainly health, education and monetary).

Ravallion and Chen $(2003)^{4}$ considered that a growth is pro-poor if the distribution of its fruits is contributing to reduce poverty. They proposed to measure the pro-poor growth rate through multiplying the ordinary rate of growth by the "distributional correction", determined by the changes in poverty over time to the changes observed under neutral distribution.

$$
\text { Rate of pro-poor growth }=\text { Distributional Correction X Ordinary Growth Rate }
$$

If the changes recorded in the distribution are in favor of the poor, then we could argue that pro-poor growth is higher than the ordinary rate of growth. Some recent empirical literature attempted to investigate the impact of growth on inequality distribution, researchers highlighted that growth seems to be neutral on average to improve the distribution inequality over time.

As alternative to measure the pro-poor growth in developing countries, Kakwani and Pernia $(2000)^{5}$ came up with their built their proper pro-poor growth indicator. Based on this indicator, the authors underlined that economic growth in South Korea contributed to reduce poverty over the period 1997 - 1999. For Thailand and Lao PDR, economic growth did not contribute strictly to improve the living conditions of poor classes.

Ravallion and Datt (2001) ${ }^{6}$ conducted an empirical research to identify the impact of growth on various states of India, as evidence regarding the existence of pro-poor growth. The authors found that spending of poor population did not depend on the changes of their income. They also advocated that in urban regions the impact of pro-poor growth is more obvious to identify.

According to Dorward et al $(2004)^{7}$, the pro-poor growth could not contribute to eradicate poverty in developing countries without enhancing the productivity of the agricultural sector. The authors carried out their empirical research by relying on a panel of countries from Sub-Saharan Africa and South Asia over the period 1987 - 1998. Poverty in these regions predominates in the rural sector. As such, any improvement of the income in this sector should be associated with a reduction of poor population. These findings are in line with the outcome of the research conducted by Fan et al. (2008) ${ }^{8}$. The latter investigate the impact of agriculture on poor population in India over the period 1960 - 1990. In their study, they attempted to determine the effect of several investments in agriculture and to analyze the tendency of poverty. The researchers found beneficial effects of growth on the poor population and thus, they underlined the necessity of enhancing the agricultural productivity in India to reduce poverty.

\footnotetext{
${ }^{4}$ Ravallion, M., \& Chen, S. (2003). Measuring pro-poor growth. Economics letters, 78(1), 93-99.

${ }^{5}$ Kakwani, N., \& Pernia, E. M. (2000). What is pro-poor growth?. Asian development review, 18(1), 1-16.

${ }^{6}$ Ravallion, M., \& Datt, G. (2002). Why has economic growth been more pro-poor in some states of India than others?. Journal of development economics, 68(2), 381-400.

7 Dorward, A., Kydd, J., Morrison, J., \& Urey, I. (2004). A policy agenda for pro-poor agricultural growth. World Development, 32(1), 73-89.

${ }^{8}$ Fan, S., Gulati, A., \& Thorat, S. (2008). Investment, subsidies, and pro-poor growth in rural India. Agricultural Economics, 39(2), 163-170.
} 
According to Kacem (2013) $)^{9}$, pro-poor growth had a positive impact on poverty in rural region of Ethiopia between 2004 and 2009. The author introduced some monetary and non-monetary indicators in the measure of "pro-poor growth". The researcher found glaring discrepancies in the measurements. Moreover, the empirical research regarding the impact of growth on households of rural regions in Ethiopia revealed that growth was anti-poor.

\subsection{Macroeconomic Policies in Favor of Pro-Poor Growth}

The abundant theoretical background discussing the issue of pro-poor growth in developing countries emphases on the significance of adopting specific macroeconomic policies to ensure the record of a growth that will improve the sort and the leaving conditions of poor populations. The advances in theories highlighted the significance of macroeconomic stability (notably, inflation, budget deficit, foreign exchange reserves) and the development of the private sector.

The record of a pro-poor growth needs some particular aspects of the macroeconomic framework of the developing country. The thorough review of the literature allowed defining some significant aspects regarding an optimal macroeconomic framework able to register a beneficial growth for poor population.

\subsubsection{Macroeconomic Framework Reflecting Confidence}

The macroeconomic stability is a good indicator for domestic investment and foreign capital inflows. The theoretical background analyzing the relationship between stability and capital inflows underlined that over the long term, stability would raise the confidence of economic actors and induce a rise in growth to eradicate poverty.

\subsubsection{Business Environment Transparent}

The transparency of the commercial and administrative environment made up one of the most significant variables affecting the choice on private and foreign investors.

For investors, the transparency of economic environment should take a significant attention in legal and administrative components.

For the legal environment, the creation of legal texts that are in favor of creating business and facilitating trade and respecting the property rights.

For the administrative environment, adopting a transparent and an effective system, to avoid the complicated procedures favors business and eases the access to public services.

\subsubsection{Control of Inflation}

The control of inflation made up the major feature of an appropriate macroeconomic policy targeting to alleviate poverty. According to theoretical advances, inflation harms quickly the leaving conditions of poor population. Its impact on other social classes remains limited due to the diversity of their portfolio.

\footnotetext{
${ }^{9}$ Kacem, R. B. H. (2013). Monetary versus non-monetary pro-poor growth: Evidence from rural Ethiopia between 2004 and 2009. Economics: The Open-Access, Open-Assessment E-Journal, 7(2013-26), 1-22.
} 


\subsubsection{Sustainable Debt-To-GDP Ratio}

A high debt-to-GDP ratio indicates a weak solvency of the country, alarming its economic situation. This affects negatively economic growth and thus, reduces the poverty eradication. The harmful impact is due to the decrease in investments and the capital outflows of foreign investors into the destination of countries with sustainable debt ratio.

\section{Empirical Investigation}

The empirical study of the paper focuses on estimating the effect of growth on poverty for a panel of 10 developing countries (Algeria, Chile, Colombia, Egypt, Morocco, Paraguay, Peru, Tunisia and Venezuela) over the period 1990 - 2012. The current empirical research should contribute to find out the actual effect of growth on poverty of the developing countries since the declaration of the last serious initiative to eradicate poverty: the Millennium Development Goals $^{10}$ in 1990.

\subsection{Presentation of the Model}

The paper attempted to determine the real impact of growth on poverty in developing countries, through estimating the following model:

$$
H P I_{i t}=C+\text { Growth }_{i t}+H D I_{i t}+X_{i t}+\varepsilon_{i t}
$$

\subsubsection{The Dependent Variable}

The Human Poverty Index (HPI), developed by the UNDP indicates the poverty degree of a country. It is built to cover new specific approaches to measure poverty.

\subsubsection{The Explanatory Variables}

The model includes also several explanatory variables that could have an impact on the evolution of human poverty in developing countries.

- The variable Growth $_{i}$ is calculated as the year-on-year growth rate of real GDP per capita recorded in country $i$. The variable $H D I_{i}$ represents the Human development indicator, as created by the UNDP and provides a measure the development degree of country i.

- $\mathrm{X}$ is a vector of explanatory variables containing various macroeconomic indicators. Which could affect the poverty evolution in developing countries. These variables include:

$\circ$ The inflation rate, measured as the year-on-year growth rate of the consumer price index;

o Trade openness, defined as the sum of total exports and imports over GDP.

○ The secondary school enrollment rate: we used enrollment rate in secondary schools to measure the contribution of human capital in reducing the poverty.

\footnotetext{
${ }^{10}$ Jaouadi, S. (2011). «L'efficacité de l'aide publique au développement et la réalisation des ODM : cas des donneurs », Revue tunisienne d'économie $n^{\circ} 16$, Centre de Publication Universitaire.
} 
o Health expenses are computed as the sum of sums up the share of governmental expenses attributed to the health sector by GDP.

o Expenses in goods and services provide insights regarding the contribution of government to finance the necessary needs of population.

- $\mathrm{i}$ : identifies the countries in the equation.

- $\mathrm{t}$ : indicates the time in the model.

\subsubsection{Data Sources}

The variables selected in the model are mainly collected from two different sources. HDI and HPI data are gathered from the annual reports of human development made publicly available by the UNDP. The other macroeconomic indicators are taken from the World Bank database (World Development Indicators 2014).

\subsection{Findings and Discussions}

Table 1. Presents the estimation output of the model.

\begin{tabular}{|l|l|l|}
\hline Explanatory Variables Dependent variable & HPI & P-Value \\
\hline Trade openness & -0.22 & 0.010 \\
\hline HDI & -1.89 & 0.003 \\
\hline Expenses on Health & -0.55 & 0.000 \\
\hline Expenses on goods and services & -0.1 & 0.000 \\
\hline Secondary enrollment & 0.28 & 0.005 \\
\hline Inflation rate & 0.02 & 0.026 \\
\hline year-on-year growth rate of real GDP per capita & 0.0309048 & 0.831 \\
\hline Constant & 7.3 & 0.000 \\
\hline R-sq: within & 0.7232 & \\
\hline Between & 0.3412 & \\
\hline Overall & 0.3840 & \\
\hline
\end{tabular}

Regarding the coefficients obtained from the estimation, it arose that openness had a harmful impact regarding the increase of poverty. A $1 \%$ increase in the trade openness is associated with a $0.22 \%$ decrease in the poverty of the country. The openness of markets contributed to raise competition among domestic markets, it led to a decrease of the prices and thus it contributed to enhance the purchase power of poor population. Referred to the handbook of McCulloch $(2001)^{11}$, the author recognized that openness and free trade contributed to lower poverty in developing countries.

The variable HDI contributes to reduce poverty in developing countries. The findings revealed that an increase of $1 \%$ in the HDI score is joined by a reduction in HPI by $1.9 \%$, the beneficial effect is statistically significant at $1 \%$. By definition, an improvement in HDI reflected an enhancement in conditions living in the country, it ends by reducing the poverty share. The present illustration is in accordance with the findings of Cervantes-Godoy and Dewbre $(2010)^{12}$, the authors stressed that "exceptional progress in reducing poverty also

\footnotetext{
${ }^{11}$ McCulloch, N., Winters, L. A., \& Cirera, X. (2001). Trade liberalization and poverty: A handbook. London.

12 Cervantes-Godoy, D., \& Dewbre, J. (2010). Economic importance of agriculture for poverty reduction.
} 
posted improvements in their HDI scores".

The expenses on health contributed to significantly decrease the poverty in the developing countries. In fact, an increase in the budget allocated for health contributes for example to enhance the infrastructure of hospitals and to provide better services for patients. Referred to Liu et al $(2003)^{13}$, the authors highlighted that overall poverty rate in China is the direct result of the decrease in medical expenses in the 1990's.

The impact of the expenses of government on poverty is in line with those allocated to health, the effect is statistically significant at $1 \%$. This suggests that government expenses contributed to improve the living conditions of poor and facilitated the access to food and necessary needs. The major programs formulated by the government to help poor populations rely on transfers from income tax to finance their needs. For Vickery $(1977)^{14}$, the starting point to fight poverty focuses on the governmental transfer programs which targets to provide income tax to poor population.

Surprisingly, the enrollment in secondary school is positively related with poverty. It means that a $1 \%$ rise in the enrollment rate is associated with a $0.28 \%$ increase in poverty. Although, the thorough analysis of the outcome authorized to denote that developing countries made investments in education to satisfy conditionalities of international institutions and continue to receive foreign aid. This policy created an educated class of population in joblessness after graduation, leading to an increase of the poverty. In accordance to Blank and Blinder (1985) ${ }^{15}$, unemployment had negative repercussions on poor population as they stressed: "unemployment bears upon the poor" and they argued: "rise in unemployment decreases the income share of the lowest quintiles".

Inflation is positively related to poverty. The effect is statistically significant at $5 \%$. A $1 \%$ increase in inflation is associated with a $0.02 \%$ rise in the poverty index. The illustration of the effect of inflation relies on the deterioration of purchasing power of poor class in developing countries, due to the decline recorded in real wage of the poor. Referring to Cardoso (1992), poverty was the main factor that decreased real wages of the poor in several countries. The author argued: "the decline in the real wages of the poor was primarily a result of the rise in inflation before 1964" 16.

Regarding the objective of the paper i.e. determining the impact of growth on poverty, the estimation underlines that growth has a positive impact on poverty. However, its effect is not statistically significant. The outcome authorized to denote that the growth recorded by the countries of the study has a harmful impact on poor classes. The ambiguous effect of growth could be the result of the inequalities in distributing the growth among different social classes, as argued by Bourguignon (2004). Regarding the ambiguous effect of growth from the empirical investigation, Bourguignon (2004) argued: "reduce inequality through

\footnotetext{
${ }^{13}$ Liu, Y., Rao, K., \& Hsiao, W. C. (2003). Medical expenditure and rural impoverishment in China. Journal of Health, Population and Nutrition, 216-222.

14 Vickery, C. (1977). The time-poor: A new look at poverty. Journal of human Resources, 27-48.

15 Blank, R. M., \& Blinder, A. S. (1985). Macroeconomics, income distribution, and poverty.

${ }^{16}$ Cardoso, E. (1992). Inflation and poverty (No. w4006). National Bureau of Economic Research.
} 
redistribution of through promoting pro-poor growth" ${ }^{\text {"17 }}$.

The empirical findings show that economic growth is not necessary beneficial regarding the enhancement of the conditions of life of the poor. The equality of the redistribution among the social classes of the country continue to play a pivotal role to reduce the share of population living in miserable conditions. In previous empirical studies, growth effectively contributed to decrease poverty in several developing countries, with better indicators of wealth redistribution.

\section{Conclusion}

The present paper attempted to bear out the real effect of growth on poverty of developing countries, to find out which developing countries benefit from economic growth. The paper underlined the neutral impact of growth on poverty evolution in developing countries. The effect of growth on human poverty index is not statistically significant.

The overview of recent studies regarding the topic of pro-poor growth concept in developing countries raised the significance of fairness in wealth redistribution among social classes, as argued by Warr (2005) ${ }^{18}$. The fairness of income redistribution in developing countries made up a pivotal issue to discuss, it is highly involved to make from economic growth a new tool to alleviate poverty in developing countries. Thus, introducing data about redistribution of income in developing would allow to assess if the mechanism of redistribution is effective and thus, if it affects the existence of pro-poor growth in developing countries.

Also, it seems that the utilization of data regarding the monetary poverty could help to find out the real effect of growth on poverty in developing countries. The lack of detailed data about the consumption of households or distribution of revenues among the various classes of the population makes up the major vulnerability to carry out more refined research.

\section{References}

Blank, R. M., \& Blinder, A. S. (1985). Macroeconomics, income distribution, and poverty.

Bourguignon, F. (2004). The poverty-growth-inequality triangle. Poverty, Inequality and Growth, 69.

Cardoso, E. (1992). Inflation and poverty (No. w4006). National Bureau of Economic Research. http://dx.doi.org/10.3386/w4006

Cervantes-Godoy, D., \& Dewbre, J. (2010). Economic importance of agriculture for poverty reduction.

Dorward, A., Kydd, J., Morrison, J., \& Urey, I. (2004). A policy agenda for pro-poor $\begin{array}{llll}\text { agricultural } \quad \text { growth. } \quad \text { World } & \text { Development, }\end{array}$ http://dx.doi.org/10.1016/j.worlddev.2003.06.012

Easterly, W. (2003). IMF and World Bank structural adjustment programs and poverty. In

${ }_{17}$ Bourguignon, F. (2004). The poverty-growth-inequality triangle. Poverty, Inequality and Growth, 69.
Warr, P. (2005). Pro-poor Growth. Asian-Pacific Economic Literature, 19(2), 1-17. 


\section{Macrothink}

Business and Economic Research ISSN 2162-4860 2016, Vol. 6, No. 2

Managing currency crises in emerging markets (pp. 361-392). University of Chicago Press. http://dx.doi.org/10.7208/chicago/9780226155425.003.0012

Fan, S., Gulati, A., \& Thorat, S. (2008). Investment, subsidies, and pro-poor growth in rural $\begin{array}{llll}\text { India. } & \text { Agricultural } & \text { Economics, } & \text { 39(2), }\end{array}$ http://dx.doi.org/10.1111/j.1574-0862.2008.00328.x

Jaouadi, S. (2011), l'efficacité de l'aide publique au développement et la réalisation des ODM : cas des donneurs, Revue tunisienne d'économie $n^{\circ} 16$, Centre de Publication Universitaire.

Kacem, R. B. H. (2013). Monetary versus non-monetary pro-poor growth: Evidence from rural Ethiopia between 2004 and 2009. Economics: The Open-Access, Open-Assessment E-Journal, 7(2013-26), 1-22.

Kakwani, N., \& Pernia, E. M. (2000). What is pro-poor growth?. Asian development review, 18(1), 1-16.

Liu, Y., Rao, K., \& Hsiao, W. C. (2003). Medical expenditure and rural impoverishment in China. Journal of Health, Population and Nutrition, 216-222.

McCulloch, N., Winters, L. A., \& Cirera, X. (2001). Trade liberalization and poverty: A handbook. London.

Ravallion, M., \& Chen, S. (2003). Measuring pro-poor growth. Economics letters,78(1), 93-99. http://dx.doi.org/10.1016/S0165-1765(02)00205-7

Ravallion, M., \& Datt, G. (2002). Why has economic growth been more pro-poor in some states of India than others?. Journal of development economics, 68(2), 381-400. http://dx.doi.org/10.1016/S0304-3878(02)00018-4

Vickery, C. (1977). The time-poor: A new look at poverty. Journal of human Resources, 27-48. http://dx.doi.org/10.2307/145597

Warr, P. (2005). Pro-poor Growth. Asian-Pacific Economic Literature, 19(2), 1-17.

\section{Copyright Disclaimer}

Copyright for this article is retained by the author(s), with first publication rights granted to the journal.

This is an open-access article distributed under the terms and conditions of the Creative Commons Attribution license (http://creativecommons.org/licenses/by/3.0/). 